\title{
AMHTS における乳房健診の検討
}

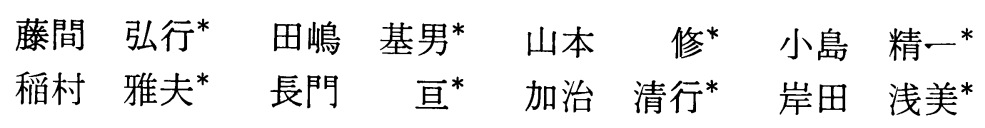

藤間病院総合健診システムにおける，昭和 48 年 2 月か ら，昭和 54 年 9 月までの受診者は 30,297 名で，ちち女は 8,998名 $(29.7 \%$ ) である。

開設以来, 女全例に乳房健診を行って来た。健診方法 は,（1）問診,（2）視・触診, （3）Mammography を行い, 必要に応じて, 穿刺細胞診を行ってきた。 Mammography は当初間接撮影法による Simple Mammography であったが, 昭和50年11月以降は Xeroradiography を導入し, 昭和 53 年 11 月以後は全例に Xeroradiography を行って1,223例に達したので，その 成績を検討した。癌は 4 例0.04\%である。

今回は AMHTS における成績と埼玉県における Mammography 併用の乳癌集検について言及し, AMHTS の乳房健診のあり方について考察してみた。

\section{(1) AMHTS の成績}

1,223 例の 1 次検診の成續における触診と Xeroradiography の所見を比較してみた。触診のみの有所見は118 例 $9.7 \%$ ，触診と Xeroradiography では 182 例 $14.9 \%$ となる。触診では癌の疑 2 例であるが, Xero. では癌 2 例, 疑 2 例と向上し, 触診で乳腺腫瘍から癌 1 例, 異常 なし例から癌の疑 1 例の発見は Xero. の価値を示すも のである。

これに関連して，注目すべきは，触診で異常なし 1,105 例のなかから癌の疑 1 例, 疑を含めて乳腺腫瘍 32 例, 乳 腺症 23 例, 石灰化その他 44 例合計 100 例 $9 \%$ が有所見と されたことである。

精検の成績について検討してみた。

Xeroradiography 併用以後の癌は 2 例で, 穿刺細胞 診で確診され, 手術を行ったもので, 所謂 Interval Cancer であった。

癌の疑 2 例は生検で乳腺腫瘍と乳腺症であった。 症例 (1)は, 67 ○で, 7 年前の健診で右乳腺 線 維 腺 腫, 左は異常なしであったが，今回左に腫瘤を触知し， Xero. で定型的な硬癌であった。症例( 2 )は, 45 ㅇで, 2 年前に健診で著変なしとされたが, 今回腫瘤を触知

\section{Screening for Breast cancer at AMHTS \\ * 藤間病院総合健診システム}

し, Xero. で微細石灰化像を伴った腫瘍陰影で，手術の 結果乳頭腺管癌であった。

乳癌の死亡率が急上昇している現状では, AMHTS で婦人健診は子宮癌のみでなく, 乳房検診を積極的に実 施すべきである。

\section{（2）埼玉県の乳癌集検の成績について}

埼玉県では昭和 46 年 12 月から昭和 54 年 3 月までに 86, 919名の検診を行っており，検診方法は，問診，視・ 触診, 間接 Mammography を全例に行っている。受診 者の年代別では, 30 代が最も多く, 過半数に近く, 40 代，50代がこれに次いで多い。

有所見者は 4,977 名 $5.7 \%$, 目下確定癌数 53 例 $0.06 \%$, 年代別の発見癌は加齡と共に増加している。自覚症状で は,しこり，いたみを訴えるものが約半数あるが, 自覚 症状なしが 9 例 $17 \%$ あった。

$\mathrm{T}$ 分類では, TIS (carcinoma in situ) 4, $\mathrm{T}_{0} 1, \mathrm{~T}_{1}$ $12, \mathrm{~T}_{2} 29, \mathrm{~T}_{3} 6, \mathrm{~T}_{4} 1$ で $\mathrm{T}_{3}$ は半数が死亡している。 TIS, $T_{0}$ の発見は集検の価值を示すものである。

病期分類では, I 期 13 , II 期 27 , III期 9 である。 N分 類では, $\mathrm{N}_{0} 22, \mathrm{~N}_{1 \sim 3}$ 個 14, $\mathrm{N}_{4}$ 以上 12 で, TIS, $\mathrm{T}_{0}, \mathrm{~T}_{1}$, $\mathrm{I}$ 期, $\mathrm{N}_{0}$ 症例では何れも死亡例はない。乳房健診の目 標はここにあると云える。

触診所見と Mammography 所見について，53例の癌 についてみると, 注目すべきことは, 触診で何等かの所 見で発見したものは53例中45例，Mammography では， 触診で異常なし 8 例中 6 例は癌の疑その他で摘発してい るので 53 例中 51 例になるが, 残り 2 例は後日, 所謂 Interval cancer として発見された。

埼玉県の乳癌集検において, Mammography 併用の 価值を示している。

AMHTS における乳房健診においては, 日本対ガン 協会の標準方式である「問診, 視・触診法」を中心とし て，施設健診であるから補助診断法として，X線被曝を 考慮しつつ Mammography (Low dose の Mammography, Xeroradiography）か超音波診断法を併用し， 診断効率を高めることが必要である。 